\title{
PERANCANGAN APLIKASI UNTUK PERHITUNGAN PENGARUH DISIPLIN KERJA DAN PENGEMBANGAN KARIR TERHADAP KINERJA KARYAWAN
}

\author{
Reni Febrianti ${ }^{1}$ \\ Program Studi Akuntansi \\ Universitas Mohammad Husni Thamrin \\ nibhot@gmail.com
}

\author{
Gunawan ${ }^{2}$ \\ Program Studi Manajemen dan Bisnis \\ Universitas Mohammad Husni Thamrin
}

\begin{abstract}
ABSTRAK
Penelitian ini bertujuan untuk mengembangkan aplikasi untuk menghitung dan menganalisis Pengaruh Disiplin Kerja dan Pengembangan Karir Terhadap Kinerja Karyawan Pada PT. Intelix Global Crossing. Penelitian ini menggunakan metode kuantitatif dengan pendekatan asosiatif. Adapun variabel yang dihubungkan dalam penelitian ini adalah variabel Disiplin Kerja $\left(\mathrm{X}_{1}\right)$, Pengembangan Karir $\left(\mathrm{X}_{2}\right)$, dan variabel Kinerja Karyawan $(\mathrm{Y})$.

Sumber data yang digunakan terdiri dari data primer yaitu data yang diperoleh langsung dari responden penelitian melalui kuesioner, wawancara, observasi. Populasi dan sampel pada penelitian ini adalah karyawan PT. Intelix Global Crossing yang berjumlah 70 orang. Pengujian dilakukan dengan menggunakan aplikasi desktop. Hasil yang didapat dari penelitan ini menunjukkan bahwa secara simultan Disiplin Kerja dan Pengembangan Karir berpengaruh positif dan signifikan terhadap kinerja karyawan pada PT. Intelix Global Crossing. Berdasarkan hasil uji parsial (uji t) dapat disimpulkan bahwa variabel Disiplin Kerja mempunyai pengaruh yang signifikan terhadap kinerja karyawan karena nilai $t_{\text {hitung }}(114,172)>t_{\text {tabel }}(1,670)$ dengan signifikansi $0,000<$ 0,05. Dan Pengembangan Karir juga mempunyai pengaruh yang signifikan terhadap kinerja pegawai karena nilai $t_{\text {hitung }}$ $(1,927)>t_{\text {tabel }}(1,670)$ dengan signifikansi $0,059<0,005$. Variabel disiplin kerja memiliki pengaruh yang dominan yaitu sebesar 1,401 dibanding dengan pengembangan karir yang hanya sebesar 0,141. Analisis koefisien determinasi. Nilai Adjusted R-Square yang diperoleh adalah sebesar 0,779 menunjukkan sekitar $78 \%$ variabel Y (kinerja karyawan) dapat dijelaskan oleh variabel disiplin kerja $\left(\mathrm{X}_{1}\right)$ dan variabel pengembangan karir $\left(\mathrm{X}_{2}\right)$. Atau secara praktis dapat dikatakan bahwa kontribusi disiplin kerja dan pengembangan karir terhadap variabel kinerja karyawan adalah $78 \%$.
\end{abstract}

\section{Kata Kunci : Aplikasi desktop, Displin Kerja,} Pengembangan Karir, Kinerja Karyawan

\section{Pendahuluan}

Karier merupakan persepsi pribadi sikap dan perilaku seseorang yang terkait dengan aktivitas-aktivitas dan pengalaman-pengalaman dalam rentang perjalanan pekerjaan seseorang. Pada PT. Intelix Global Crossing dalam pengembangan karir karyawan membutuhkan waktu yang cukup lama yaitu kurang lebih 5 tahun sehingga banyak karyawan yang mengeluh dalam pengembangan karir di perusahaan tersebut.

Menurut Ambarwati (2016:6) disiplin kerja adalah suatu alat yang digunakan para manajer untuk berkomunikasi dengan karyawan agar mereka bersedia untuk mengubah suatu perilaku serta sebagai suatu upaya untuk menigkatkan kesadaran dan kesediaan seseorang menaati semua peraturan perusahaan dan norma-norma sosial yang berlaku. Disiplin kerja pada perusahaan akan meningkatnya ketepatan waktu dalam bekerja sehingga karyawan akan bertanggung jawab atas pekerjaannya. Pada PT.Intelix Global Crossing banyak karyawan yang tidak disiplin pada jam kerja yang sudah ditetapkan oleh perusahaan. Beberapa karyawan tidak masuk kerja tanpa surat keterangan dan tidak ada laporan kepada pimpinan.

Menurut Puji Hartatik (2014), pengertian kinerja adalah kemampuan atau prestasi kerja yang telah dicapai oleh para personil atau sekelompok orang dalam suatu organisasi, untuk melaksanakan fungsi, tugas dan tanggung jawab mereka dalam menjalankan operasional perusahaan.

PT. Intelix Global Crossing adalah perusahaan pengembang software dan system integrator yang fokus pada computer telephony untuk solusi komunikasi dan perusahaan. Didukung oleh manajemen dan staff berpengalaman, Intelix memberikan layanan dalam bidang Contact Center dengan brand name e-CentriX.

\section{Tinjauan Pustaka}

Kinerja berasal dari pengertian performance. Ada pula yang memberikan pengertian performance sebagai hasil kerja atau prestasi kerja. Namun, sebenarnya kinerja mempunyai makna yang lebih luas, bukan hanya hasil kerja, tetapi termasuk bagaimana proses pekerjaan berlangsung.

Menurut Armstrong dan Baron dalam Wibowo (2016:7) kinerja merupakan hasil pekerjaan yang mempunyai hubungan kuat dengan tujuan strategis organisasi, kepuasan konsumen, dan memberikan kontribusi pada ekonomi.

Menurut Mangkunegara (2013:67) pengertian kinerja (prestasi kerja) adalah hasil kerja secara kualitas dan kuantitas yang dicapai oleh seorang pegawai dalam melaksanakan tugasnya sesuai dengan tanggung jawab yang diberikan kepadanya. 
Menurut Bangun (2012:231-232) kinerja adalah hasil pekerjaan yang dicapai seseorang berdasarkan persyaratanpersyaratan tertentu untuk dapat dilakukan dalam mencapai tujuan yang disebut juga sebagai standar pekerjaan.

Penilaian kinerja merupakan salah satu tugas penting untuk dilakukan oleh seorang manajer atau pimpinan. Walaupun demikian, pelaksanaan kinerja yang obyektif bukanlah tugas yang sederhana. Penilaian kinerja ini harus disertai metode-metode yang memungkinkan agar didapat penilaian yang obyektif.

Disiplin kerja sangatlah penting bagi suatu perusahaan atau instansi pemerintah dalam rangka mewujudkan tujuan perusahaan. Tanpa adanya disiplin kerja yang baik sulit bagi suatu perusahaan untuk mencapai hasil yang optimal. Disiplin yang baik mencerminkan besarnya tanggung jawab seseorang terhadap tugas-tugas yang diberikan kepadanya.

Menurut (Novitasari, 2017:30) disiplin kerja adalah sebagai suatu sikap menghormati, menghargai, patuh dan taat terhadap peraturan-peraturan yang berlaku, baik yang tertulis maupun yang tidak tertulis serta sanggup menjalankannya dan tidak mengelak untuk menerima sanksi-sanksi apabila ia melanggar tugas dan wewenang yang diberikan kepadanya.

Dari definisi di atas dapat disimpulkan bahwa disiplin kerja adalah sikap kesediaan dan kerelaan seseorang untuk patuh dan taat terhadap peraturan-peraturan yang berlaku, baik yang tertulis maupun yang tidak tertulis serta sanggup menjalankannya dan tidak mengelak untuk menerima sanksisanksi apabila ia melanggar tugas dan wewenang yang diberikan kepadanya.

Pengembangan karir (carreer development) adalah suatu kondisi yang menunjukkan adanya peningkatan status seseorang dalam suatu organisasi yang bersangkutan (Yulita,2017:436) pengembangan karir adalah usaha yang dilakukan secara formal dan berkelanjutan dengan difokuskan pada peningkatan dan penambahan kemampuan seseorang.

Menurut Marwansyah (2012:208) pengembangan karir adalah kegiatan-kegiatan pengembangan diri yang ditempuh oleh seseorang untuk mewujudkan rencana karir pribadinya.

Pengembangan karir sangat diharapkan oleh setiap pegawai untuk memotivasi mereka dalam bekerja dengan baik (Yulita, 2017:437). Pengembangan karir merupakan gabungan dari kebutuhan pelatihan di masa yang akan datang dan perencanaan sumber daya manusia. Dari sudut pandang pegawai, pengembangan karir memberikan gambaran mengenai jalur-jalur karir di masa yang akan datang di dalam organisasi terhadap para pegawainya. Bagi organisasi, pengembangan karir memberikan jaminan bahwa akan tersedia pegawai-pegawai yang akan mengisi posisi-posisi yang akan lowong di waktu mendatang.

Berdasarkan teori di atas mengenai pengertian pengembangan karir, maka dapat disimpulkan bahwa pengembangan karir adalah proses peningkatan jenjang karir seorang karyawan melalui program yang direncanakan dan diterapkan oleh suatu perusahaan.

Pengembangan karir pada dasarnya bertujuan untuk memperbaiki dan meningkatkan efektivitas pelaksanaan pekerjaan para pekerja agar semakin mampu memberikan kontribusi terbaik dalam mewujudkan tujuan organisasi.

\section{Metodologi Penelitian}

Waktu dan tempat penelitian dilaksanakan pada bulan Januari 2019 hingga selesai di PT. Intelix Global Crossing yang bertempat di Jl. Gg. Duren Tiga No.17, RT.8/RW.5, Duren Tiga, Kec. Pancoran, Kota Jakarta Selatan. Adapun populasi dalam penelitian ini adalah karyawan PT. Intelix Global Crossing yang berjumlah 70 karyawan.

Menurut Sugiyono ( $2014: 116$ ), sampel adalah sebagai berikut : "Sampel merupakan bagian dari jumlah dan karakteristik yang di miliki oleh populasi tersebut". Pengukuran sampel merupakan suatu langkah untuk menentukan besarnya sampel yang di ambil dalam melaksanakan suatu penelitian, selain itu juga diperhatikan bahwa sampel yang dipilih harus menunjukan segala karakteristik populasi sehingga tercermin dalam sampel yang dipilih, dengan kata lain sampel harus dapat menggambarkan keadaan populasi yang sebenarnya atau mewakili (representatif).

Untuk menghitung penentuan jumlah sampel dari populasi tertentu maka digunakan rumus Slovin sebagai berikut :

$$
n=\frac{N}{1+N e^{2}}
$$

\section{Dimana :}

$\mathrm{n}:$ Jumlah Sampel

$\mathrm{N}$ : Jumlah Populasi

$\mathrm{e}^{2}$ : Taraf nyata atau batas kesalahan

Dalam menentukan jumlah sampel yang akan dipilih, penulis menggunakan tingkat kesalahan sebesar 5\% karena dalam setiap penelitian tidak mungkin hasilnya sempurna $100 \%$. Makin besar tingkat kesalahan maka semakin sedikit ukuran sampel. Jumlah Populasi sebagai dasar perhitungan yang digunakan adalah 70 orang. Dengan perhitungan sebagai berikut :

$$
\begin{gathered}
n=\frac{N}{1+N e^{2}} \\
n=\frac{70}{1+70 \times 0,05^{2}} \\
n=\frac{70}{1+70 \times 0,0025} \\
n=59.574
\end{gathered}
$$


Jika di bulatkan menjadi 60 responden. Jadi, jumlah sampel yang diambil adalah 60 responden di PT.Intelix Global Crossing.

Definisi operasional adalah definisi yang didasarkan atas sifat-sifat hal yang didefinisikan yang dapat diamati atau diobservasi. Suryabrata (2012). Adapun definisi operasional penelitian adalah sebagai berikut:

\section{a. Variabel Disiplin Kerja (X1)}

Disiplin adalah sikap kesediaan dan kerelaan seseorang untuk mematuhi dan menaati norma-norma peraturan yang berlaku di sekitarnya.

b. Variabel Pengembangan Karir (X2)

Pengembangan karir adalah kegiatan-kegiatan pengembangan diri yang ditempuh oleh seseorang untuk mewujudkan rencana karir pribadinya.

Variabel dependent adalah variabel yang dipengaruhi atau menjadi akibat karena adanya variabel bebas. Adapun yang menjadi variabel dependent dari penelitian ini adalah:

\section{Variabel Kinerja Karyawan}

Kinerja karyawan adalah salah satu faktor yang digunakan untuk melihat keberhasilan suatu organisasi. Baik buruknya kinerja pegawai akan sangat berpengaruh pada kinerja instansi atau keberhasilan suatu organisasi.

Kuesioner merupakan teknik pengumpulan data primer yang dilakukan dengan cara memberikan pernyataan tertulis kepada responden. Dalam penelitian ini, peneliti membagikan angket langsung kepada karyawan PT.Intelix Global Crossing dengan bertujuan untuk mengetahui pendapat responden mengenai terkait hal yang diteliti oleh penulis. Dalam penelitian ini responden adalah karyawan PT.Intelix Global Crossing dengan menggunakan skala likert, dimana setiap pertanyaan mempunyai 5 opsi yaitu:

Tabel 1. Instrumen Skala Likert

\begin{tabular}{|l|l|c|}
\hline No. & Skala & Skor \\
\hline 1 & Sangat Setuju & 5 \\
\hline 2 & Setuju & 4 \\
\hline 3 & Kurang Setuju & 3 \\
\hline 4 & Tidak Setuju & 2 \\
\hline 5 & Sangat Tidak Setuju (STS) & 1 \\
\hline
\end{tabular}

\section{Pembahasan}

Penelitian ini menggunakan 60 responden yang digunakan untuk menguraikan sejauh mana faktor-faktor promosi dan mutasi mempengaruhi kinerja karyawan. Karakteristik responden yaitu menguraikan deskripsi identitas responden menurut sampel penelitian yang telah ditetapkan. Salah satu tujuan deskripsi karakteristik responden dan rekaputulasi jawaban responden adalah memberikan gambaran yang menjadi sampel dalam penelitian.
Berdasarkan Hasil Pengumpulan Data Melalui Kuesioner Kepada karyawan PT. Intelix Global Crossing yang dijadikan sebagai responden maka dapat diketahui karakteristik responden. Penelitian sampel, karakteristik dikelompokan menurut Jenis Kelamin, Usia responden, Pendidikan, dan Lama Bekerja.

Berdasarkan karakteristik usia responden dapat dijelaskan melalui tabel di bawah ini :

Tabel 2. Presentase Usia Responden

\begin{tabular}{|l|l|l|}
\hline Usia & Frekuensi (Orang) & Presentase (\%) \\
\hline 30-40 Tahun & 45 & $75 \%$ \\
\hline 41-50 Tahun & 13 & $22 \%$ \\
\hline 51-60 Tahun & 2 & $3 \%$ \\
\hline Jumlah & 60 & $100 \%$ \\
\hline
\end{tabular}

Karakteristik responden berdasarkan jenis kelamin

Tabel 3. Presentase Jenis Kelamin Responden

\begin{tabular}{|l|l|l|}
\hline Jenis Kelamin & Frekuensi (Orang) & Presentase (\%) \\
\hline Laki-Laki & 47 & $78 \%$ \\
\hline Perempuan & 13 & $22 \%$ \\
\hline Jumlah & 60 & $100 \%$ \\
\hline
\end{tabular}

Karakteristik responden berdasarkan pendidikan terakhir

Tabel 4. Presentase pendidikan terakhir responden

\begin{tabular}{|l|l|l|}
\hline $\begin{array}{l}\text { Pendidikan } \\
\text { Terakhir }\end{array}$ & $\begin{array}{l}\text { Frekuensi } \\
\text { Orang) }\end{array}$ & Presentase (\%) \\
\hline D3 & 4 & $7 \%$ \\
\hline S1 & 50 & $83 \%$ \\
\hline S2 & 6 & $10 \%$ \\
\hline Jumlah & 60 & $100 \%$ \\
\hline
\end{tabular}

Berdasarkan hasil penelitian yang telah dilakukan terhadap 60 responden melalui penyebaran kuesioner, didapatkan kecenderungan jawaban responden terhadap jawaban dari masing-masing variabel akan didasarkan pada rentang skor jawaban.

Variabel disiplin kerja pada peneliian ini diukur melalui 8 butir pertanyaan yang mempresentasikan indikatorindikator dari variabel tersebut. Hasil tanggapan responden terhadap variabel Disiplin Kerja dapat dijelaskan pada tabel

TABEL 5. TANGGAPAN RESPONDEN TERHADAP VARIABEL DISIPLIN KERJA

\begin{tabular}{|l|l|l|l|}
\hline NO & Pernyataan & $\begin{array}{l}\text { Rata-rata } \\
\text { Skor }\end{array}$ & Keterangan \\
\hline 1 & $\mathrm{X} 1.1$ & 4,33 & Sangat Setuju \\
\hline 2 & $\mathrm{X} 1.2$ & 4,26 & Sangat Setuju \\
\hline 3 & $\mathrm{X} 1.3$ & 3,86 & Sangat Setuju \\
\hline 4 & $\mathrm{X} 1.4$ & 3,98 & Sangat Setuju \\
\hline 5 & $\mathrm{X} 1.5$ & 3,9 & Sangat Setuju \\
\hline 6 & $\mathrm{X} 1.6$ & 3,66 & Sangat Setuju \\
\hline 7 & $\mathrm{X} 1.7$ & 4,11 & Sangat Setuju \\
\hline 8 & $\mathrm{X} 1.8$ & 4,15 & Sangat Setuju \\
\hline
\end{tabular}


Berdasarkan hasil tabel diatas bahwa mayoritas responden sangat setuju pada variabel disiplin kerja sehingga dapat dikatakan bahwa disiplin kerja yang diterapkan relatif mendukung kinerja karyawan pada perusahaan PT. Intelix Global Crossing.

Variabel pengembangan karir pada penelitian ini diukur melalui 9 butir pernyataan yang mempresentasikan indicatorindikator dari variabel tersebut. Hasil tanggapan responden terhadap variabel pengembangan karir dapat dijelaskan pada tabel berikut:

\section{TABEL 6. TANGgAPAN RESPONDEN TERHADAP VARIABEl PENGEMbangan KariR}

\begin{tabular}{|l|l|l|l|}
\hline NO & Pernyataan & $\begin{array}{l}\text { Rata-rata } \\
\text { Skor }\end{array}$ & Keterangan \\
\hline 1 & X2.1 & 4,06 & Sangat Setuju \\
\hline 2 & X2.2 & 2,31 & Kurang Setuju \\
\hline 3 & X2.3 & 3,8 & Sangat Setuju \\
\hline 4 & X2.4 & 4,31 & Sangat Setuju \\
\hline 5 & X2.5 & 3,35 & Setuju \\
\hline 6 & X2.6 & 3,63 & Setuju \\
\hline 7 & X2.7 & 4,13 & Sangat Setuju \\
\hline 8 & X2.8 & 4,08 & Sangat Setuju \\
\hline 9 & X2.9 & 4,06 & Sangat Setuju \\
\hline
\end{tabular}

Berdasarkan hasil tabel diatas bahwa mayoritas responden sangat setuju pada variabel pengembangan karir sehingga dapat dikatakan bahwa pengembangan karir yang diterapkan relatif mendukung kinerja karyawan pada perusahaan PT. Intelix Global Crossing.

Variabel Kinerja Karyawan pada penelitian ini diukur melalui 14 butir pernyataan yang mempresentasikan indicator- indikator dari variabel tersebut. Hasil tanggapan responden terhadap variabel kinerja karyawan dapat dijelaskan pada tabel berikut:

\section{TABEL 7. TANGgAPAN RESPONDEN TERHADAP} VARIABEL KINERJA KARYAWAN

\begin{tabular}{|l|l|l|l|}
\hline NO & Pernyataan & $\begin{array}{l}\text { Rata-rata } \\
\text { Skor }\end{array}$ & Keterangan \\
\hline 1 & Y.1 & 3,98 & Sangat Setuju \\
\hline 2 & Y.2 & 3,9 & Sangat Setuju \\
\hline 3 & Y.3 & 3,66 & Setuju \\
\hline 4 & Y.4 & 4,11 & Sangat Setuju \\
\hline 5 & Y.5 & 4,15 & Sangat Setuju \\
\hline 6 & Y.6 & 4,48 & Sangat Setuju \\
\hline 7 & Y.7 & 4,48 & Sangat Setuju \\
\hline 8 & Y.8 & 4,33 & Sangat Setuju \\
\hline 9 & Y.9 & 4,01 & Sangat Setuju \\
\hline 10 & Y.10 & 4,56 & Sangat Setuju \\
\hline 11 & Y.11 & 4,28 & Sangat Setuju \\
\hline 12 & Y.12 & 4,23 & Setuju \\
\hline 13 & Y.13 & 4,21 & Sangat Setuju \\
\hline 14 & Y.14 & 4,21 & Sangat Setuju \\
\hline
\end{tabular}

Berdasarkan hasil tabel diatas bahwa mayoritas responden sangat setuju pada variabel kinerja karyawan sehingga dapat dikatakan bahwa kinerja yang diterapkan relatif mendukung kinerja karyawan pada perusahaan PT. Intelix Global Crossing.

Uji validitas ini untuk mengukur sah atau valid tidaknya suatu kuisioner. Suatu kuisioner dikatakan valid jika pertanyaan pada kuisioner mampu untuk mengungkapkan sesuatu yang akan diukur oleh kuisioner tersebut

Adapun hasil uji validitas variabel bebas dan variabel terikat adalah sebagai berikut :

Tabel 8. Hasil Uji Validitas Disiplin Kerja (X1)

\begin{tabular}{|l|l|l|l|}
\hline Pernyataan & r hitung & r tabel & Keterangan \\
\hline X1.1 & 0,762 & 0,2500 & Valid \\
\hline X1.2 & 0,710 & 0,2500 & Valid \\
\hline X1.3 & 0,815 & 0,2500 & Valid \\
\hline X1.4 & 0,673 & 0,2500 & Valid \\
\hline X1.5 & 0,639 & 0,2500 & Valid \\
\hline X1.6 & 0,774 & 0,2500 & Valid \\
\hline X1.7 & 0,537 & 0,2500 & Valid \\
\hline X1.8 & $\underline{0,531}$ & $\underline{0,2500}$ & $\underline{\text { Valid }}$ \\
\hline
\end{tabular}

Berdasarkan hasil uji validitas disiplin kerja yang terlihat pada tabel 8 dapat dilihat bahwa seluruh pernyataan tersebut memiliki kolerasi diatas atau lebih besar dari $\mathrm{r}$ tabel yang telah ditetapkan yaitu 0,2500. Jadi dapat ditarik sebuah kesimpulan bahwa 8 item pernyataan tersebut dikatakan memenuhi syarat validitas.

Tabel 9. Hasil Uji Validitas Pengembangan Karir (X2)

\begin{tabular}{|l|l|l|l|}
\hline Pernyataan & $r$ hitung & $r$ tabel & Keterangan \\
\hline X2.1 & 0,382 & 0,2500 & Valid \\
\hline X2.2 & 0,552 & 0,2500 & Valid \\
\hline X2.3 & 0,655 & 0,2500 & Valid \\
\hline X2.4 & 0,491 & 0,2500 & Valid \\
\hline X2.5 & 0,718 & 0,2500 & Valid \\
\hline X2.6 & 0,689 & 0,2500 & Valid \\
\hline X2.7 & 0,414 & 0,2500 & Valid \\
\hline X2.8 & 0,633 & 0,2500 & Valid \\
\hline X2.9 & 0,537 & 0,2500 & Valid \\
\hline
\end{tabular}

Berdasarkan hasil uji validitas pengembangan karir yang terlihat pada tabel 9 dapat dilihat bahwa seluruh pernyataan tersebut memiliki kolerasi diatas atau lebih besar dari $r$ tabel yang telah ditetapkan yaitu 0,2500 . Jadi dapat ditarik sebuah kesimpulan bahwa 9 item pernyataan tersebut dikatakan memenuhi syarat validitas. 
Tabel 10. Hasil Uji Validitas Kinerja (Y)

\begin{tabular}{|l|l|l|l|}
\hline Pernyataan & r hitung & $r$ tabel & Keterangan \\
\hline Y1 & 0,434 & 0,2500 & Valid \\
\hline Y2 & 0,687 & 0,2500 & Valid \\
\hline Y3 & 0,608 & 0,2500 & Valid \\
\hline Y4 & 0,688 & 0,2500 & Valid \\
\hline Y5 & 0,482 & 0,2500 & Valid \\
\hline Y6 & 0,635 & 0,2500 & Valid \\
\hline Y7 & 0,494 & 0,2500 & Valid \\
\hline Y8 & 0,721 & 0,2500 & Valid \\
\hline Y9 & 0,673 & 0,2500 & Valid \\
\hline Y10 & 0,622 & 0,2500 & Valid \\
\hline Y11 & 0,734 & 0,2500 & Valid \\
\hline Y12 & 0,869 & 0,2500 & Valid \\
\hline Y13 & 0,870 & 0,2500 & Valid \\
\hline Y14 & 0,799 & 0,2500 & Valid \\
\hline
\end{tabular}

Berdasarkan hasil uji validitas kinerja karyawan yang terlihat pada tabel diatas dapat dilihat bahwa seluruh pernyataan tersebut memiliki kolerasi diatas atau lebih besar dari $r$ tabel yang telah ditetapkan yaitu 0,2500. Jadi dapat ditarik sebuah kesimpulan bahwa 14 item pernyataan tersebut dikatakan memenuhi syarat validitas.

Uji reabilitas dilakukan untuk mengukur suatu kuesioner yang merupakan indikator dari variabel atau konstruk. Karena suatu kuesioner dikatakan reliabel atau handal jika jawaban seseorang terhadap pernyataan adalah konsisten atau stabil dari waktu ke waktu. Kehandalan yang menyangkut kekonsistenan jawaban jika diujikan berulang pada sampel yang berbeda. Adapun hasil hasil uji reliabilitas adalah sebagai berikut.

Tabel 11. Hasil Uji Reabilitias Reability Statistic

\begin{tabular}{|c|c|c|}
\hline Variabel & $\begin{array}{c}\text { Cronbach } \\
\text { Alpha }\end{array}$ & Keterangan \\
\hline $\begin{array}{c}\text { Pengaruh Disiplin } \\
\text { Kerja }\left(\mathrm{X}_{1}\right)\end{array}$ & 0,845 & Reliabel \\
\hline $\begin{array}{c}\text { Pengaruh } \\
\text { Pengembangan } \\
\text { Karir }\left(\mathrm{X}_{2}\right)\end{array}$ & 0,727 & Reliabel \\
\hline $\begin{array}{c}\text { Pengaruh Kinerja } \\
\text { Karyawan }(\mathrm{Y})\end{array}$ & 0,901 & Reliabel \\
\hline
\end{tabular}

Dasarkan hasil perhitungan dengan bantuan program dapat dilihat pada data diatas bahwa nilai Croncbach's Alpha dari 60 orang responden, dengan variable pengaruh displin kerja dan pengembangan karir terhadap kinerja karyawan memiliki tingkat reliabilitas lebih besar dari 0,60. Sehingga dapat ditarik sebuah kesimpulan bahwa dari setiap item-item pernyataan disetiap variabel penelitian dinyatakan reliabel.

Uji normalitas bertujuan untuk menguji apakah dalam model regresi, variabel bebas dan variabel terikat, keduanya terdistribusikan secara normal atau tidak. Normalitas data dalam penelitian dilihat dengan cara memperhatikan titik-titik pada Normal P-Plot of Regression Standardized Residual dari variabel terikat.

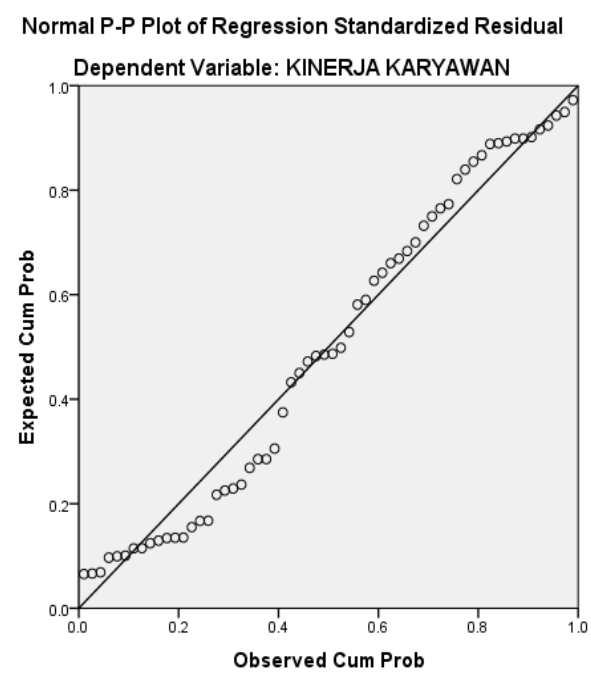

Gambar 1. Hasil Uji Normalitas

Berdasarkan output "Chart" diatas, dapat dilihat bahwa titik-titik ploting yang terdapat pada gambar "Normal P-P Plot of Regression Standardized Residual" selalu mengikuti dan mendekati garis diagonalnya maka model regresi memenuhi asumsi normalitas. Dengan demikian maka asumsi normalitas untuk nilai residual dalam analisis regresi liniear berganda dalam penelitian ini dapat terpenuhi.

Uji multikolinearitas dilakukan untuk mendeteksi ada tidaknya kolerasi yang kuat antara variabel bebas dalam model regresi, Regresi yang baik mengasumsikan tidak ada multikolinearitas. Pendeteksian ada tidaknya multikolineritas dilakukan dengan melihat nilai tolerance dan VIF. Apabila nilai tolerance $>0,1$ dan VIF $<10$, maka model regresi bebas dari multikolinearitas.

Uji heteroskedisitas bertujuan untuk menguji apakah dalam sebuah model regresi terjadi ketidaknyamanan varian dari residual satu pengamatan ke pengamatan lain. Jika varian berbeda, disebut heteroskedastisitas. Berikut adalah uji Heterokedasitas secara grafik atau Uji Heterokedasitas scatterplot dilakukan untuk melihat ada tidaknya pola tertentu pada grafik scatterplot. 


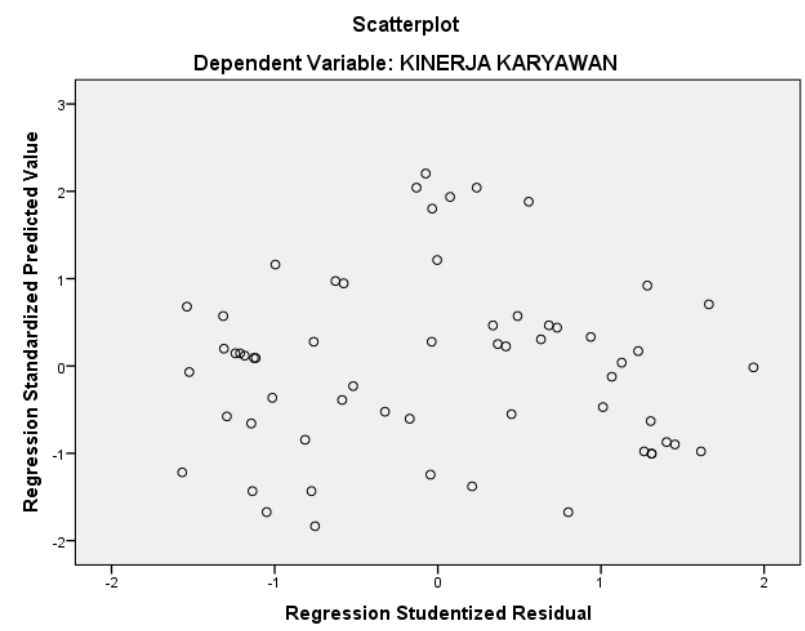

Gambar 2. Hasil Uji Heterokedisitas scatterplot

Gambar 2 menunjukkan bahwa titik-titik data penyebar di atas dan dibawah atau disekitar angka 0 , titik-titik mengumpul hanya di atas atau di bawah saja, penyebaran titik data tidak membentuk pola bergelombang dan melebar kembali dan penyebaran pada titik-titik data tidak berpola. Maka dari itu dapat ditarik sebuah kesimpulan bahwa tidak terjadi masalah dalam heteroskedastisitas, sehingga model regresi yang baik dan ideal dapat terpenuhi.

Tabel 12.

Hasil Uji Regresi Linier Berganda karyawan dianggap tetap.

2. Koefesien regresi variabel Displin Kerja 1,401 menyatakan bahwa setiap penambahan variabel sebesar 1 satuan, maka terjadi kenaikan kinerja karyawan dengan asumsi yang bernilai tetap

3. Koefesien regresi variabel Pengembangan Karir 0,141 menyatakan bahwa setiap penambahan variabel sebesar 1 satuan, maka terjadi kenaikan kinerja karyawan dengan asumsi yang bernilai tetap.

Pengujian hipotesis digunakan untuk mengetahui ada atau tidaknya pengaruh anatara variabel independen terhadap dependen, adapun hasil pengujiannya sebagai berikut :

Uji t pada dasarnya menunjukan seberapa jauh pengaruh suatu variabel penjelasan secara individual dalam menerangkan variabel terikat. Sugiyono (2016:269). Adapun prosedurnya sebagai berikut : apabila nilai signifikansi $<0,05$ maka Ha diterima atau $\mathrm{t}$ hitung $>\mathrm{t}$ tabel maka Ha diterima. Demikian pula sebaliknya jika sig $>0,05$ atau $t$ hitung $>t$ tabel,maka Ho diterima.

Nilai $t_{\text {hitung }}$ sebesar 1,927 dan $t_{\text {tabel }} 1,670$ dengan tingkat signifikan sebesar $0,059>0,05$. Ini artinya variabel pengembangan karir tidak berpengaruh positif dan tidak signifikan terhadap kinerja karyawan PT Intelix Global Crossing.

Uji Simultan (Uji F) Digunakan untuk mengetahui hubungan dan pengaruh antara variabel bebas dan variabel terikat secara keseluruhan atau secara simultan. Menurut Sugiono (2016:297)

\begin{tabular}{|c|c|c|c|c|c|}
\hline \multirow[b]{2}{*}{ Model } & \multicolumn{2}{|c|}{$\begin{array}{l}\text { Unstandardized } \\
\text { Coefficients }\end{array}$} & \multirow{2}{*}{$\begin{array}{l}\text { Standardized } \\
\text { Coefficients } \\
\text { Beta }\end{array}$} & \multirow[b]{2}{*}{$\mathrm{t}$} & \multirow[b]{2}{*}{ Sig. } \\
\hline & B & Std. Error & & & \\
\hline 1 (Constant) & 8,665 & 4,200 & & 2,063 & ,044 \\
\hline DISIPLIN KERJA & 1,401 & ,099 & 884 & 14,172 & ,000 \\
\hline $\begin{array}{l}\text { PENGEMBANGAN } \\
\text { KARIR }\end{array}$ & ,141 & ,073 & 120 & 1,927 & ,059 \\
\hline
\end{tabular}

a. Dependent Variable: KINERJA KARYAWAN

Berdasarkan hasil yang telah diperoleh dari kofesien regresi di atas, maka dapat dibuat suatu persamaan regresi sebagai berikut:

$$
\mathrm{Y}=8,665+1,401 \mathrm{X} 1+0,141 \mathrm{X} 2+\mathrm{e}
$$

Dimana :

$\mathrm{Y}=$ Kinerja

$\mathrm{X} 1=$ Disiplin Kerja

$\mathrm{X} 2=$ Pengembangan Karir

$\mathrm{e}=$ Standar Eror

Berdasarkan perhitungan di atas dapat disimpulkan sebagai berikut:

1. Konstanta sebesar 8,665 artinya jika variabel Disiplin Kerja (X1) dan Pengembangan (X2) adalah 0 (nol) maka kinerja karyawan nilainya adalah 8,665 dengan asumsi variabel- variabel lain yang dapat memengaruhi kinerja
Tabel 13. Hasil Uji F Anova

\begin{tabular}{|c|c|c|c|c|c|}
\hline Model & $\begin{array}{ll}\text { Sum } & \text { of } \\
\text { Squares }\end{array}$ & Df & $\begin{array}{l}\text { Mean } \\
\text { Square }\end{array}$ & $\mathrm{F}$ & Sig. \\
\hline 1 Regression & 1621,065 & 2 & 810,533 & 100,745 & $.000^{\mathrm{b}}$ \\
\hline Residual & 458,585 & 57 & 8,045 & & \\
\hline Total & 2079,650 & 59 & & & \\
\hline
\end{tabular}

a. Dependent Variable: KINERJA KARYAWAN

b. Predictors: (Constant), PENGEMBANGAN KARIR, DISIPLIN KEI

Dapat dilihat nilai $\mathrm{f}_{\text {hitung }}$ sebesar $100.745>$ nilai $\mathrm{f}_{\text {tabel }}$ 2,76 dan nilai signifikan sebesar $0,000<0,05$ maka dapat di simpulkan bahwa variabel independent yaitu dispilin kerja dan pengembangan karir secara bersama sama berpengaruh positif dan signifikan terhadap variabel dependen yaitu kinerja karyawan. 
Kofesien Determinasi r2 pada intinya mengukur seberapa jauh kemampuan model dalam menerangkan variabel independen

\section{Tabel 14. Hasil Kofesien Determinasi}

\begin{tabular}{|l|l|l|l|l|l|}
\hline Model & $\mathrm{R}$ & $\mathrm{R}$ Square & $\begin{array}{l}\text { Adjusted R } \\
\text { Square }\end{array}$ & $\begin{array}{l}\text { Std. Error of } \\
\text { the Estimate }\end{array}$ & $\begin{array}{l}\text { Durbin- } \\
\text { Watson }\end{array}$ \\
\hline 1 & $.883^{\mathrm{a}}$ &, 779 &, 772 & 2,836 & 1,859 \\
\hline
\end{tabular}

a. Predictors: (Constant), Pengembangan Karir, Disiplin Kerja

b. Dependent Variable: Kinerja Karyawan

Berdasarkan tabel diatas dapat dilihat bahwa angka koefisien determinasi $\mathrm{R}^{2}$ ( $\mathrm{R}$ Square) adalah sebesar 0,779. Jadi sumbangan pengaruh dari variabel displin kerja $\left(\mathrm{X}_{1}\right)$ dan pengembangan karir $\left(\mathrm{X}_{2}\right)$ yaitu sebesar $78 \%$. Sedangkan sisanya $22 \%$ (100\%-78\%) dipengaruhi oleh faktor lain diluar peneltian.

Berikut ini pembahasan hipotesis penelitian:

1. H1 : Disiplin kerja berpengaruh terhadap kinerja karyawan berdasarkan $\mathrm{t}$ hitung 114,172 > t tabel 1,670 dan nilai sig $0,000<0,05$. Jadi dapat disimpulkan disiplin kerja memiliki pengaruh signifikan terhadap kinerja. Diperkuat dengan penelitian terdahulu yang dilakukan oleh Enjang Mya Afiyati pada tahun 2018 yang berjudul "Pengaruh Pengembangan Karir, Motivasi Kerja, dan Disiplin Kerja Terhadap Kinerja Karyawan Bank Syariah Mandiri Cabang Surakarta dari hasil tersebut disiplin kerja berpengaruh secara positif dan signifikan terhadap variable kinerja.

2. H2 : Pengembangan karir tidak berpengaruh terhadap kinerja karyawan berdasarkan t hitung 1,927 $>\mathrm{t}$ tabel 1,670 dan nilai sig $0,059<0,05$ jadi dapat disimpulkan mutasi tidak memiliki penngaruh signifikan terhadap kinerja karyawan. Diperkuat dengan penelitian terdahulu yang dilakukan oleh Deborah Regina Tabita Kasenda,Rita Taroreh, dan Lucky Dotulong berjudul "Pengaruh Pengembangan Karir dan Disiplin Kerja Terhadap Kinerja Karyawan Pada PT. Bank Sulutgo Cabang Kawangkoan pada tahun 2016 dari hasil tersebut pengembangan karir tidak berpengaruh secara signifikan terhadap variabel kinerja.

3. H3 : Promosi disiplin kerja dan pengembangan karir terhadap Kinerja karyawan yang menyatakan F hitung $100.745>$ f tabel 2,76 dan nilai signifikansi lebih kecil dari alpha $(0,000<0,05)$. Dari hasil tersebut maka keputusan yang di ambil adalah menolak HO dan $\mathrm{Ha}$ diterima, artinya secara simultan disiplin kerja dan pengembangan karir secara keseluruhan mempunyai pengaruh yang signifikan terhadap kinerja karyawan.

Diperkuat dengan penelitian terdahulu yang dilakukan oleh Enjang Mya Afiyati pada tahun 2018 dari hasil penelitian terbukti bahwa variabel disiplin kerja dan pengembangan karir memberikan pengaruh terhadap kinerja karyawan. Hubungan antara disipin kerja dan pengembangan karir terhadap kinerja karyawan sangat kuat. Disiplin kerja dan pengembangan karir merupakan salah satu kegiatan yang penting dalam pengembangan karyawan karena dengan adanya disiplin kerja dan pengembangan karir dapat memberi motivasi kepada karyawan untuk meningkatkan kinerjanya.

\section{Penutup}

\section{Kesimpulan}

Kesimpulan dari penelitian Disiplin Kerja dan Pengembangan Karir Terhadap Kinerja Karyawan Pada PT. Intelix Global Crossing.

1. Berdasarkan hasil uji $\mathrm{t}$ disiplin kerja berpengaruh terhadap kinerja hal ini dilihat dari t hitung 114,172 dengan $\mathrm{t}$ tabel 1,670 jadi $\mathrm{t}$ hitung $>\mathrm{t}$ tabel dengan nilai signifikansi $0,000<0,05$.

2. Berdasarkan hasil uji t pada pengembangan karir tidak berpengaruh terhadap kinerja hal ini dilihat dari t hitung 1,927 dengan $t$ tabel 1,670 jadi $t$ hitung $>t$ tabel dengan nilai signifikansi $0,059<0,05$

3. Berdasarkan hasil Uji $F$ (simultan) menunjukan bahwa nilai $f$ hitung lebih besar dari $\mathrm{f}$ tabel (F hitung 100.745 > $\mathrm{F}$ tabel 2,76) dan nilai signifikansi lebih kecil dari alpha $(0,000<0,05)$. Secara simultan disiplin kerja dan pengembangan karir berpengaruh terhadap kinerja karyawan.

4. Berdasarkan hasil Uji Koefisien Determinasi diperoleh sebesar 78\%. Menunjukkan bahwa variabel kinerja dapat dijelaskan variabel disiplin kerja dan pengembangan karir sebesar $78 \%$ dan sisanya $22 \%$ dijelaskan faktorfaktor lain yang tidak diteliti.

\subsection{Saran}

Guna meningkatakan kineja karyawan diberikan saran sebagai berikut :

Perlu upaya PT. Intelix Global Crossing, untuk meningkatkan kedisplinan yang lebih kepada karyawan, agar karyawan dapat lebih bertanggung jawab, memiliki rasa tanggung jawab dan keberanian untuk melakukan inovasi pada proses kerja diperusahaan sebagai perwujudan dari keberadaan disiplin kerja yang tinggi dalam diri para karyawan.

Agar kinerja karyawan tetap baik, maka perusahaan harus selalu mempertahankan dan meningkatkan pengembangan karir kepada kinerja karyawannya agar kinerja menjadi meningkat.

Bagi peneliti selanjutnya, yang ingin melakukan penelitian sejenis disarankan untuk mencari dan lebih mengembangkan faktor-faktor penting yang berpengaruh terhadap kinerja karyawan. 


\section{Daftar Pustaka}

Debora Regina Tabita Kasenda, Rita Taroreh, Lucky Dotulong (2016). Pengaruh Pengembangan Karir dan Disiplin Kerja Terhadap Kinerja Karyawan PT. Bank Sulutugo Cabang Kawangkoan, Universitas Sam Ratulangi, Manado.

Maskarto Lucky Nara Rosmadi (2018). Pengaruh Pelatihan, Disiplin, dan Pengembangan Karir Terhadap Kinerja Karyawan Out Sourching PT. Gardautama, STIE Kridatama, Bandung.

Faustyna, Jamani (2015). Pengaruh Pengembangan Karir dan Disiplin Kerja Terhadap Kinerja Karyawan Pada PT. Pelabuhan Indonesia (PERSERO) Medan, Universitas Muhamaddiyah Sumatera Utara.

Nia Uli Silitongo, Seno Andri (2017), Pengaruh Pengembangan Karir dan Disiplin Kerja Terhadap
Kinerja Karyawan Pada PT. PLN (PERSERO) Area Pekanbaru Rayon Kota Timur, Universitas RIAU.

Enjang Mya Afyati (2018), Pengaruh Pengembangan Karir, Motivasi Kerja, dan Disiplin Kerja Terhadap Kinerja Karyawan Pada Bank Syariah Mandiri Cabang Surakarta, IAIN Salatiga.

Alimah, Anisatul. (2017). "Analisis pengaruh Komunikasi, Lingkungan KerjaDan Disiplin KerjaTerhadap Kinerja Karyawan (Studi Kasus Pada BTN Syariah Cabang Semarang)." Skripsi. Jurusan Perbankan Syariah. Fakultas Ekonomi Dan Bisnis Islam. IAIN Salatiga.

Leti Marjanuardi dan Sri Langgeng Ratnasari (2019), "Pengaruh disiplin kerja, loyalitas, dan pengembangan karir terhadap kinerja karyawan yayasan raudlatul qur`an batam" 